\title{
KONTROVERSI PERSOALAN IMÂMAH DI KALANGAN KAUM SYI'AH
}

\author{
Mawardy Hatta \\ Fakultas Ushuluddin dan Humaniora \\ IAIN Antasari Banjarmasin \\ Diterima tanggal 3 Juli 2015 / Disetujui tanggal 10 Mei 2016
}

\begin{abstract}
Imamate is the main Shi'ite doctrine. They use the term Imam as a substitute for a degree of prophet office after his death. Shi'ites in particular Imami Itsna Asy'ari and Isma'ilism found an eligible priest to be after Prophet Muhammad's death is Ali bin Abi Talib. While the Prophet never specify who should be a priest, he only mentions the qualities of a priest and accidental properties that are owned by Ali bin Abi Talib, so Ali should be chosen become a priest. Thinking about the Imamate, Shiites refer to events that occurred in Ghadir Khum, where the prophet has returned from the Farewell Pilgrimage stopped in Ghadir area Arafah. Then, he appointed and inaugurated Ali bin Abi Thaib to be his successor as priest. This event is believed by a group of Imami Itsna Asy'ari and Isma'ilism as the basis for the appointment of Ali as priests. In addition they also use Qur'anic verses that are understood and interpreted according to their version, as a proposition or argument in strengthening the doctrine of the Imamate. While the group did not seem to wear Zaidiyyah the arguments and the Ghadir event.
\end{abstract}

Kata kunci: Imamah, Syi’ah, Imâmiah, Isma’iliyah, Zaidiyah

\section{Pendahuluan}

Salah satu aliran teologi Islam yang tumbuh dan berkembang hingga saat ini adalah Syi'ah. Syi'ah semula merupakan golongan politik yang kemudian menjadi aliran dari teologi Islam. Dilihat dari sudut doktrin teologis, aliran ini dapat dikategorikan menjadi tiga macam yaitu Syi'ah ekstrim (ghulat), Syi'ah Râfidhah, dan Syi'ah moderat.

Syi'ah ekstrim (ghulat) adalah golongan yang mempunyai doktrin atau pemikiran yang jauh menyimpang dari akidah Islam sebenarnya. Mereka menganggap Ali lebih mulia dari nabi, Ali adalah jelmaan Tuhan, ia tidak wafat melainkan diangkat ke langit, dan sebagainya. Termasuk golongan ini antara lain kelompok al-Sabâiyah, al-Ghurâbiyah, al-Mughîriyah, al-Kaisâniyah.

Golongan Râfidhah adalah golongan yang tidak mengakui kekhalifahan Abu Bakar, Umar dan Usman, bahkan mereka mencaci maki ketiga khalifah tersebut karena dianggap telah merampas hak kekhalifahan Ali. Termasuk golongan Râfidhah ini adalah Syi'ah Imâmiyah Itsna Asyariyah dan Syi'ah Isma'iliyah. Syi'ah Imamiyah Itsna Asyariyah selanjutnya hanya disebut Syi'ah Imâmiyah adalah Syi'ah yang paling banyak pengikutnya dibanding golongan lainnya. Sebagian besar mereka terdapat di Iran, Irak, Libanon, Pakistan, India dan Afrika. ${ }^{1}$

Sedangkan Syi'ah moderat adalah golongan yang doktrin atau pemikiran-pemikirannya sederhana, tidak jauh menyimpang bahkan dekat kepada paham-paham Ahlu al-Sunnah wa alJamaah. Golongan moderat ini adalah Zaidiyah. Doktrin pokok yang dimiliki aliran Syi'ah secara keseluruhan adalah tentang imamah, yaitu pemimpin yang kedudukannya sebagai pengganti 
Rasulullah setelah beliau wafat. Mereka menyebut dengan istilah imam, sementara kaum muslimin pada umumnya menyebut dengan istilah khalifah. Oleh karena aliran Syi'ah ini terpecah belah menjadi beberapa golongan atau firqah sebagaimana diungkapkan di atas, maka pemikiran tentang imamah pun juga bervariasi atau berbeda-beda di antara kaum Syi'ah tersebut.

Setiap golongan memiliki konsep sendiri tentang imamah. Doktrin Imamah merupakan persoalan kontroversial di kalangan mereka. Apa dan bagaimana kontroversi tentang doktrin imamah menurut kalangan Syi'ah tersebut, inilah yang akan dicoba untuk diungkap kembali. Namun pembahasan dibatasi hanya golongan Râfidhah yakni Imâmiyah dan Isma'îliyah serta golongan moderat yaitu Zaidiyah.

\section{Pemikiran tentang Imâmah di Kalangan Syi'ah}

Di kalangan Syi'ah, doktrin imâmah merupakan salah satu hal yang harus diimani. Beriman kepada imam merupakan rukun akidah atau iman setelah beriman kepada rasul. ${ }^{2}$ Kaum muslimin pada umumnya memakai term khalifah kepada orang yang menjadi pengganti nabi, sedangkan kaum Syi'ah memakai term imam. Imam menurut mereka adalah seorang pemimpin yang posisinya berada di muka, dan ia menjadi teladan yang harus diikuti seperti dicontohkan Rasulullah SAW dalam setiap peperangan dan lain-lain.

Kedudukan imam sama dengan khalifah yaitu pengganti rasulullah Saw sebagai pemelihara agama dan penanggung jawab urusan ummat. ${ }^{3}$ Imâmah merupakan pangkat yang disematkan Allah layaknya kenabian. Sebagaimana Allah telah memilih para hamba-Nya sebagai nabi dan rasul serta mendukungnya dengan mukjizat sebagai dalil dari Allah maka begitu pula halnya imâmah, Allah memilih orang yang dikehendaki-Nya untuk menjadi imam dan memerintahkan nabi-Nya untuk mengangkatnya sebagai imam. ${ }^{4}$

\section{Orang yang berhak menjadi imam}

Secara keseluruhan kaum Syi'ah berpendapat bahwa orang yang berhak menjadi imam pengganti rasulullah setelah beliau wafat adalah Sayyidina Ali bin Abi Thalib. Tapi walaupun mereka sepakat bahwa masalah imâmah merupakan dokrin utama yang harus ada, dan yang berhak menjadi imam itu adalah Ali bin Abi Thalib, namun terdapat perbedaan konsep, apakah berhaknya Ali menjadi imam itu atas penunjukan nabi atau tidak.

Syi'ah Imamiyah dalam masalah ini berpendapat bahwa nabi telah menunjuk Ali menjadi Imam melalui sebuah wasiat di Ghadir Khum sebuah daerah di sekitar Arafah sepulang dari haji wada'. Di tempat ini rasulullah telah menunjuk Ali menjadi imam untuk menggantikan beliau. Menurut mereka, Rasulullah juga menegaskan bahwa imam yang sah berjumlah 12 orang sebagaimana diriwayatkan oleh kaum Syi'ah sendiri: "Imam-imam sesudahku adalah 12 orang, yang pertama Ali bin Abi Thalib dan yang terakhir adalah al-Qaim (imam yang ke-12). Mereka adalah khalifahku, wâshi-ku, dan pembantuku serta juga bujjah Allah atas umatku sesudahku. Mengakui mereka adalah mukmin, sedangkan yang mengingkari mereka adalah kafir." Imam yang 12 itu

${ }^{2}$ Ahmad Daudy, Kuliah Ilmu Kalam, 40.

${ }^{3}$ Suyuthi Pulungan, Fikih Siyasah, Ajaran, Sejarah dan Pemikiran (Jakarta: Rajawali Press, 1994), 59.

${ }^{4}$ Ali Muhammad Ash Shalabi, Khawarij dan Syi'ab dalam Timbangan Ablu Sunnab wal Jamaah (Jakarta: Pustaka AlKautsar, 2012), 166.

${ }^{5}$ Ali Muhammad Ash Shalabi, Khawarij dan Syi'ah, 39. 
adalah: Ali bin Abi Thalib, Hasan bin Ali, Husein bin Ali, Ali bin Husein, Muhammad al-Baqier, Ja'far al-Shadiq, Musa al-Kazhim, Ali bin Musa al-Kazhim, Muhammad bin Ali, Ali bin Muhammad al-Hadi, Hasan bin Ali al-Askari dan Muhammad bin Hasan al-Mahdi. Imam yang kedua belas ini diyakini telah hilang atau gaib pada tahun $260 \mathrm{H}$, pada usia sekitar 5 atau 6 tahun. Mereka meyakini bahwa imam yang gaib itu akan kembali menjelang hari kiamat nanti untuk menegakkan keadilan setelah dunia dipenuhi oleh berbagai kezaliman. ${ }^{6}$ Imam kedua belas yang akan kembali ini diberi gelar dengan Imam Mahdi al-Muntazhar.

Menurut kaum Syi'ah, Rasulullah bukan sekedar menyebut sifat-sifat imam tetapi juga menunjuk orangnya yang menjadi imam yaitu Ali bin Abi Thalib. Mereka berpendapat tidak ada yang terpenting dalam agama Islam selain dari menunjuk imam. Diangkatnya imam adalah untuk menghilangkan semua perselisihan dan untuk mempersatukan umat. Ali bin Abi Thalib telah ditunjuk menurut beberapa nas baik yang tersurat maupun yang tersirat. ${ }^{7}$ Oleh karena Ali telah ditunjuk nabi menjadi imam yang sah, maka dengan demikian, kekhalifahan Abu Bakar dan Umar bin Khattab serta Usman bin Affan tidak sah, bahkan dianggap telah merampas hak Ali dalam kekhalifahan. ${ }^{8}$

Menurut mereka, rasulullah memandang bahwa masalah imâmah adalah masalah penting, yang tidak bisa ditentukan atau dipilih oleh umat melainkan ditetapkan oleh Allah. Karenanya beliau diperintah Allah untuk menentukan siapa pengganti beliau setelah wafat, yang berperan menjadi rujukan dan pegangan umatnya. Ali adalah orang yang telah dipilih atau ditunjuk Nabi untuk menjadi imam berdasarkan nas darinya.?

Sementara itu, golongan Syi'ah Isma'iliyah mempunyai pendirian yang relatif sama bahwa Nabi telah menunjuk Ali bin Abi Thalib untuk menjadi imam pengganti beliau. Namun berbeda dengan Imamiyah yang mempercayai 12 orang imam, golongan Isma'iliyah hanya mempercayai 7 orang imam. Karennya golongan ini disebut pula dengan Syi'ah Sab'iyyah. Mulai imam pertama sampai imam keenam, mereka sepakat dengan Syi'ah Imamiyah. Tapi pada imam ketujuh, terjadilah perbedaan pendapat. Jika Syi'ah Imamiyah meyakini bahwa imam ketujuh adalah Musa al-Kazhim, maka golongan Isma'iliyah mempercayai bahwa imam ketujuh adalah Isma'il bin Ja'far yang merupakan kakak dari Musa al-Kazhim. Karenanya mereka dinamakan Syi'ah Isma'iliyah. Menurut mereka Ja'far al-Shadiq sebagai imam keenam telah menobatkan Isma'il menjadi imam ketujuh. Tetapi Ismail wafat ketika ayahnya masih hidup. Walaupun demikian, mereka tetap menerapkan nas penunjukan tersebut, sehingga keimaman Isma'il terus berlanjut walaupun ia sudah wafat. Prinsip mereka adalah mengamalkan nash lebih baik daripada meninggalkannya. ${ }^{10}$

Golongan Isma'iliyah ini kemudian terpecah menjadi dua kelompok, pertama kelompok yang mempercayai bahwa Isma'il yang telah wafat itu akan kembali ke dunia, dan mereka menunggu kedatangannya. Kedua adalah kelompok yang berpendapat bahwa karena Isma'il telah wafat, maka yang menjadi imam adalah Muhammad putera dari Isma'il sendiri. Kelompok ini berpendapat bahwa Ja'far al-Shadiq telah menunjuk Isma'il menjadi imam, namun karena Isma'il wafat ketika ayahnya masih hidup, maka imâmah dipindahkan kepada cucunya atau anak Isma'il yaitu Muhammad. ${ }^{11}$ Semenjak itu, muncullah doktrin imam tersembunyi atau tertutup, karena mereka menetapkan bahwa seorang imam bisa saja tersembunyi dan tetap wajib dipatuhi. Tersembunyinya imam tidak

${ }^{6}$ Ali Assalus, Imamah dan dan Khilafah dalam Tinjauan Syar'i (Jakarta: Gema Insani Press, 1997). 40.

7Al-Syahrastani, Al-Milal wa al-Nibal (Cairo: Muassasah al-Halaby, 1968), 162.

${ }^{8}$ Abu Zahrah, Tarikh Mazahib al-Islamiyyah (Cairo Mesir: Dar al-Fikr al-'Araby, t.th.), 18.

${ }^{9} \mathrm{Abu}$ Zahrah, Tarikh Mazabib al-Islamiyyah, 56.

${ }^{10} \mathrm{Abu}$ Zahrah, Tarikh Mazahib al-Islamiyyah, 63.

${ }^{11}$ Ali Assalus, Imamah dan dan Khilafah, 35. 
menghalangi seseorang untuk menjadi imam. ${ }^{12}$ Karena itulah golongan ini juga disebut sebagai kelompok al-Batbiniyah atau al-Batbiniyyun ${ }^{13}$

Golongan selanjutnya adalah Zaidiyah, mereka ini adalah pengikut Zaid bin Ali Zainal Abidin. Golongan ini mempunyai paham-paham yang agak moderat, tidak ekstrim bahkan dekat dengan paham Ahlussunnah Waljamaah. Dalam sejarahnya, golongan ini telah mendirikan kerajaan di Yaman dengan ibukotanya San'a. Beberapa tahun silam bentuk kerajaan ini telah diubah menjadi republik melalui revolusi di negara itu. ${ }^{14}$

Tentang konsep imâmah menurut golongan Zaidiyah, memang yang berhak adalah Ali bin Abi Thalib. Tetapi menurut mereka nabi tidak pernah menentukan atau menunjuk Ali menjadi imam. Beliau hanya menyebut sifat-sifat yang menjadi persyaratan seorang imam yaitu: dari kalangan Bani Hasyim, wara', taqwa, baik, dan bergaul dengan masyarakat. Kebetulan semua sifat itu dimiliki oleh Ali, maka Alilah yang berhak menjadi imam. Mereka juga berpendapat bahwa Imam sesudah Ali haruslah dari keturunan Fatimah. Namun begitu, tak menuntup kemungkinan imam dipilih dari pihak luar. Itu semua merupakan syarat ideal. Jika tidak terpenuhi, boleh saja memilih imam di luar persyaratan itu apabila Abl al-Halli wal 'aqdi (Tim Pemilihan) memilih dan membai'atnya, dan itu adalah sah. Berdasarkan prinsip ini, maka kekhalifahan Abu Bakar dan Umar adalah sah. ${ }^{15}$

Selanjutnya mereka berpendapat bahwa imam boleh saja seorang yang utama walaupun ada yang lebih utama. Ali dinilai sebagai orang yang lebih utama, tapi kekhalifahannya diserahkan kepada Abu Bakar dan Umar demi menjaga kemaslahatan umat dan kaidah agama yang mereka pelihara, yaitu meredam timbulnya fitnah dan untuk menenangkan hati rakyat. ${ }^{16}$

Jadi, golongan Zaidiyah ini berbeda dengan golongan Imamiyah dan Isma'iliyah. Kedua golongan ini berpendapat bahwa yang berhak menjadi imam sesudah nabi wafat adalah Ali, bahkan nabi telah menunjuk atau memilih Ali menjadi khalifah, sehingga kekhalifahan Abu Bakar dan Umar adalah tidak sah, bahkan mereka berpendapat keduanya telah merampas hak kekhalifahan Ali bin Abi Thalib. Sementara golongan Zaidiyah berpendapat bahwa walaupun yang berhak menjadi imam adalah Ali, namun nabi tidak pernah menunjuk atau memilih Ali menjadi imam, dan karenanya maka kekhalifahan Abu Bakar dan Umar adalah sah.

\section{Kriteria dan Sifat-sifat Imam}

Pada dasarnya, kaum Syi'ah berpendapat bahwa imam harus dari keturunan Rasulullah (ahlul bait). Ini merupakan syarat utama seorang imam khususnya yang dianut oleh Syi'ah Imamiyah dan Isma'iliyah. Sedangkan golongan Zaidiyah walaupun menetapkan imam harus dari keturunan Fatimah, namun itu tidak mutlak, artinya boleh saja imam dari pihak lain, jika tak ada yang memenuhi syarat yang ditetapkan, atau karena ada pertimbangan untuk menjaga kemaslahatan dan persatuan umat.

Para imam menurut golongan Imamiyah dan Isma'iliyah bersifat ma'shûm yakni terpelihara dari kesalahan dan dosa. Imam itu sama dengan nabi dalam kema'shûman, sifat-sifat dan ilmunya. Mereka terlepas dari kesalahan dan dosa lahir maupun batin. Mereka memiliki sifat-sifat terpuji. Setiap imam menerima ilmu tentang syariat dari nabi atau imam-imam sebelumnya. Sebagian mereka berpendapat bahwa salah seorang malaikat yang mendampingi nabi untuk membimbing dan

\footnotetext{
${ }^{12} \mathrm{Abu}$ Zahrah, Tarikh Mazahib al-Islamiyyah, 63.

${ }^{13} \mathrm{Abu}$ Zahrah, Tarikh Mazahib al-Islamiyyah, 64.

${ }^{14}$ Harun Nasution, Islam Ditinjau dari Berbagai Aspeknya I (Jakarta: UI Press, 1985), 100.

${ }^{15} \mathrm{Abu}$ Zahrah, Tarikh Mazahib al-Islamiyyah, 52.

${ }^{16} \mathrm{Abu}$ Zahrah, Tarikh Mazahib al-Islamiyyah, 52.
} 
mengajar beliau. Setelah beliau wafat, malaikat itu tidak kembali ke alamnya, melainkan tetap melaksanakan tugas yang sama terhadap para imam sesudah rasulullah wafat. ${ }^{17}$

Abu Zahrah menjelaskan tentang konsep imâmah dalam golongan Syi'ah Imamiyah sebagai berikut:

a. Nabi meninggalkan rahasia-rahasia syariat untuk dititipkan kepada para imam. Nabi tidak menerangkan seluruh hukum tetapi hanya sebagiannya saja, sesuai dengan masanya, Sedangkan sebagian lagi ditinggal agar para imam penerima wasiat menerangkannya kepada kaum muslimin.

b. Perkataan imam adalah syari'at Islam. Karena ia penyempurna risalah kenabian, maka ucapan dalam bidang agama merupakan syari'at. Ucapan para imam itu setara dengan sabda nabi, karena merupakan titipan bagi mereka.

c. Imam bersifat ma'shûm (terpelihara dari kesalahan dan dosa, kelupaan dan kemaksiatan. Mereka adalah orang-orang suci dan disucikan. ${ }^{18}$

Sementara itu, kalangan Syi'ah Isma'iliyah juga meyakini bahwa imam bersifat ma'shum, namun pendapat mereka lebih jauh lagi bahwa imam tidak bertanggung jawab kepada siapapun, dan siapapun tidak boleh menyalahkannya ketika ia melakukan suatu perbuatan. Mereka wajib mengakui bahwa semua perbuatan imam mengandung kebaikan bukan keburukan, karena ia memiliki pengetahuan yang tak dimiliki oleh orang lain. Dalam pengertian inilah imam itu bersifat ma'shum, bukan dalam pengertian tak melakukan kesalahan sebagaimana yang kita pahami selama ini. Sesuatu yang kita pahami sebagai suatu kesalahan, terkadang menurut mereka ada ilmu yang menerangi seorang imam sehingga ia boleh melakukannya, sedangkan manusia lain tidak boleh. ${ }^{19}$

Berbeda dengan pemikiran di atas, golongan Zaidiyah berpendapat bahwa imam tidaklah bersifat ma'shum seperti nabi. Imam adalah seorang manusia, dan sebagai manusia bisa saja melakukan kesalahan dan dosa seperti manusia lainnya. Juga tidak ada imam yang tersembunyi atau gaib dan akan kembali menjelang hari kiamat nanti.

Jelasnya bahwa Syi'ah Imamiyah Itsna 'Asyariyah dan Isma'iliyah berpendapat bahwa Imam itu harus dari keturunan rasulullah dan bersifat ma'shûm, sedangkan Zaidiyah berpendapat bahwa imam tidak mesti dari kalangan ahlul bait, bisa saja imam dipilih dari luar dan tidak bersifat ma'shûm.

\section{Kedudukan Imam dalam Pandangan Syi'ah}

Bagi kaum Syi'ah, doktrin imâmah adalah mutlak wajib diimani sebagai bagian dari iman kepada nubuwwah. Di kalangan Syi'ah terutama golongan Imamiyah dan Isma'iliyah berpendapat bahwa imâmah merupakan bagian dari rukun Islam dan salah satu pokok keimanan. Keimanan seseorang dinilai sempurna, jika meyakininya dan suatu amal ibadah hanya diterima dengan mewujudkannya. ${ }^{20}$ Di dalam buku Ushul al-Kafi terdapat beberapa riwayat yang menempatkan kedudukan imâmah sebagai rukun Islam yang utama. Al-Kulani meriwayatkan dengan sanad yang disandarkan kepada Abu Ja'far, ia berkata: Islam dibangun atas lima pondasi: shalat, zakat, puasa, haji dan al-wilayah (imâmah). Dalam pemikiran kaum Syi'ah, Imam merupakan jabatan yang diberikan

${ }^{17}$ Ali Assalus, Imamah dan dan Khilafah, 38.

${ }^{18}$ Abu Zahrah, Tarikh Mazabib al-Islamiyyah, 59.

${ }^{19}$ Abu Zahrah, Tarikh Mazabib al-Islamiyyah, 66.

${ }^{20}$ Ali Muhammad Ash-Shalabi, Khawarij dan Syi'ah dalam Timbangan Ablu Sunnab Waljamaah, terj. Masturi Ilham \& Malik Supar (Jakarta : Pustaka Al-Kautsar, 2007), 165. 
Tuhan. Dalam sebuah hadis yang dinisbahkan kepada Ja'far al-Shadiq dinyatakan: "Barang siapa yang tidak mengakui imam zamannya, maka ia akan mati seperti matinya Jahiliyah". Kaum Syi'ah mentaqdiskan Ali dan keturunannya dengan sejumlah gelar kehormatan seperti al-Washi, al-Mabdi alMuntazhar, nabi dan Tuhan. Dengan berbagai gelar kehormtan itu, maka kedudukan seorang imam cukup tinggi dan mulia. Sebutan imam maksudnya pemimpin umat, al-Washi maksudnya penerima wasiat atau penetapan dari nabi. Sebutan nabi dan Tuhan diberikan oleh golongan Syi'ah ekstrim (gbulat) terhadap pribadi Ali yang dianggap sederajat dengan nabi, dan sebagai tetesan Tuhan atau memiliki unsur ketuhanan. ${ }^{21}$

Ditambahkan pula bahwa imam itu mempunyai tugas seperti nabi dan rasul dalam segala bidang untuk memberi petunjuk dan bimbingan ke jalan kebaikan dan kebahagiaan dunia hingga akhirat. Imam adalah uli al-amr yang harus ditaati. Perintah mereka adalah perintah Allah, dan larangan mereka adalah larangan Allah, dan melanggar perintah mereka berarti melanggar perintahNya. Karena itu, mereka wajib ditaati serta dijadikan pedoman. ${ }^{22}$ Mereka berpendapat bahwa urusan imâmah bukanlah urusan umat untuk memilih dan menentukannya, melainkan ketentuan Tuhan yang kemudian menyuruh nabi untuk memilih dan melantik Ali bin Abi Thalib dan anak cucunya untuk menjadi imam sebagai pengganti beliau. Rasul telah melaksanakan perintah Tuhan itu dengan melantik Ali bin Abi Thalib di Ghadir Khum. ${ }^{23}$

Mengingat begitu urgen dan tingginya kedudukan imam, maka menurut kaum Syi'ah Imamiyah para imam mesti ditunjuk oleh nabi, bukan dipilih oleh manusia biasa. Dalam hal ini adalah Ali bin Abi Thalib yang telah ditunjuk atau diberi wasiat oleh nabi bukan yang lainnya.

Sebagian ulama mereka berpendapat cukup ekstrim bahwa orang yang tidak mempercayai imâmah atau salah seorang imam dan tidak mentaatinya pada hal diwajibkan Allah, adalah kafir, sesat, dan pantas untuk kekal di neraka. Bahkan tokoh mereka yang bernama Ni'matullah al-Jazairi mengemukakan pendapat dengan mendeklarasikan pemisahan Syi'ah dari kaum muslimin karena masalah imâmah. Ia mengatakan: "Kami tidak sependapat dengan mereka dalam hal Tuhan, nabi, maupun imam. Sebab mereka menyatakan bahwa Tuhan mereka adalah Tuhan yang nabi-Nya adalah Muhammad dan khalifahnya adalah Abu Bakar. Sedanngkan kami tidak menyatakan Tuhan dan nabi itu. Justrukami menyatakan bahwa Tuhan yang pengganti nabi-Nya adalah Abu Bakar bukanlah Tuhan kami dan Nabi itu bukanlah nabi kami” Imâmah menurut mereka sejajar dengan kenabian, bahkan lebih agung daripadanya. Imâmah adalah pokok agama sekaligus prinsip mendasarnya. ${ }^{24}$

Sementara itu, Syi'ah Zaidiyah berpendapat bahwa seorang imam tidak harus ditunjuk oleh nabi, tetapi bisa saja dipilih melalui pemilihan oleh kaum muslimin. Karenanya, boleh saja imam dipilih selain Ali bin Abi Thalib dan itu adalah sah. Demikianlah kedudukan Imam dalam aliran Syi'ah.

\section{Dasar-Dasar Doktrin Imâmah}

Sebagaimana dijelaskan terdahulu, bahwa golongan Imamiyah dan Isma'iliyah berpendapat bahwa yang berhak menjadi imam sebagai pengganti rasul adalah Ali bin Abi Thalib, dan rasulullah telah menunjuk atau melantiknya di Ghadir Khum, daerah Arafah sepulang dari haji wada'. Ketika itu rasulullah memegang tangan Ali dan bersabda kepada kaum muslimin: Wahai jamaah muslimin.

\footnotetext{
${ }^{21}$ Ali Assalus, Imamah dan dan Khilafah, 37.

${ }^{22}$ Ali Assalus, Imamah dan dan Khilafah, 39.

${ }^{23}$ Ahmad Daudy, Kuliah Ilmu Kalam, 40.

${ }^{24}$ Ali Muhammad Ash-Shalabi, Khawarij dan Syi'ah dalam Timbangan, 170.
} 
Bukankah aku lebih utama denganmu daripada di kalian. Mereka menjawab: benar. Nabi bersabda lagi: Barang siapa yang aku adalah penolongnya, maka Ali adalah penolongnya. Ya Allah, tolonglah orang yang menolongnya dan musuhilah orang yang memusuhinya, bantulah orang yang membantunya dan hinakanlah orang yang menghinanya.Jadikanlah kebenaran besertanya di mana saja ia berada. Ketahuilah, sudahkah aku menyampaikan? $(3 \mathrm{kali}){ }^{25}$ Rasululah menurut mereka juga telah menegaskan bahwa imam itu semuanya 12 orang yang dimulai dari Ali bin Abi Thalib dan yang ke dua belas adalah al-Qaim. Mereka adalah khalifahku, washi-ku, pembantuku serta juga hujah Allah atas umatku sesudahku. Yang mengakui mereka adalah mukmin sedangkan yang mengingkari mereka adalah kafir. ${ }^{26}$

Peristiwa Ghadir Khum itu sangat terkenal di kalangan kaum Syi'ah dan menjadi dasar atau landasan dari doktrin imâmah yang mereka anut. Selain merujuk kepada riwayat di atas, mereka juga berpegang kepada ayat-ayat Al-Quran yang mereka tafsirkan menurut pemahaman mereka sendiri. Ayat-ayat tersebut adalah:

Surah al-Maidah ayat 55:

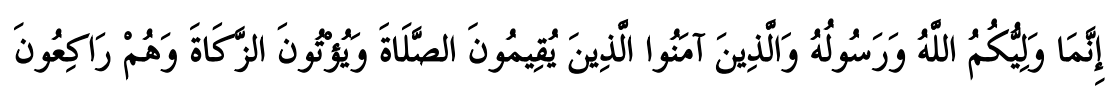

Sesunggubnya penolong kamu banyalah Allah, Rasul-Nya, dan orang-orang yang beriman, yang mendirikan shalat dan menunaikan zakat, seraya mereka tunduk (kepada Allah).

Ayat tersebut lazim mereka sebut ayat wilayah (imâmah). Ayat itu menurut mereka menunjukkan bahwa imam setelah nabi adalah Ali bin Abi Thalib, sebab lafaz innama menunjukkan arti pembatasan. Kata waliyyukum menunjukkan orang yang lebih berhak menangani urusan dan wajib ditaati. Ayat itu turun berkenaan dengan Ali yang memberi sedekah berupa cincin ketika ia sedang ruku' dalam shalat.

Kemudian pada surah Ali Imran ayat 61:

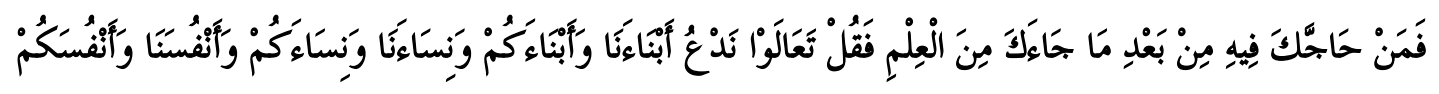

"Maka Katakanlab (kepadanya): "Marilah kita memanggil anak-anak Kami dan anak-anak kamu, isteri-isteri Kami dan isteri-isteri kamu, diri Kami dan diri kamu."

Ayat tersebut menurut kalangan Syi'ah menjelaskan bahwa rasulullah memanggil orang-orang yang akan diselimuti dengan pakaian beliau yaitu Ali, Fatimah, Hasan, dan Husein. Mereka adalah orang-orang yang paling dicintai dan merekalah yang lebih berhak memegang imâmah daripada tiga khalifah sebelum Ali. Kata anfusana (diri kami) menunjukkan Ali itu seperti Rasulullah.

Kemudian dalam surah al-Baqarah ayat 124:

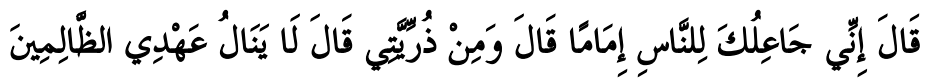

"Allab berfirman: "Sesunggubnya aku akan menjadikanmu imam bagi seluruh manusia". Ibrabim berkata: "(Dan saya mohon juga) dari keturunanku". Allah berfirman: "Janji-Ku (ini) tidak mengenai orang yang zalim"."

Ayat di atas membatalkan kepemimpinan orang-orang zalim. Sesungguhnya imâmah dikhususkan bagi keturunan Ibrahim yang bersih dari kezaliman. Orang-orang yang menyembah selain Allah termasuk perbuatan zalim. Hanya Alilah yang tidak pernah menyembah berhala, sedang khalifah lainnya pernah menyembah berhala sebelum masuk Islam, dan berarti pernah berbuat zalim.

${ }^{25}$ Ahmad Daudy, Kuliah Ilmu Kalam, 40-41.

${ }^{26}$ Ahmad Daudy, Kuliab Ilmu Kalam, 39. 
Karenanya Alilah yang berhak menjadi imam. Karena itu, mereka berpendirian bahwa Allah Swt telah memerintahkan Nabi Saw untuk mengangkat Ali sebagai pemimpin manusia setelah beliau wafat. Nabi menyadari bahwa manusia akan keberatan jika hal itu disampaikan. Nabi Saw ragu untuk menyampaikannya. Untuk menghilangkan keraguan, maka turunlah ayat 67 surah al-Maidah:

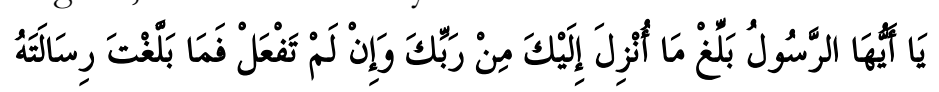

"Hai rasul, sampaikanlah apa yang diturunkan kepadamu dari Tuhanmu dan jika tidak kamu kerjakan (apa yang diperintabkan itu, berarti) kamu tidak menyampaikan amanat-Nya."

Setelah peringatan itu turun, Nabi Saw pun menyampaikan khutbah kepada manusia di Ghadir Khum sepulang dari haji wada'. Dalam khutbah itu Nabi mengatakan: "Bukankah aku lebih utama dari orang-orang beriman? Mereka berkata, betul. Nabi bersabda: Barang siapa yang aku sebagai pemimpinnya, maka Ali ini juga pemimpinnya.

Selanjutnya nabi menegaskan hal itu dalam berbagai kesempatan, dan dengan demikian nabi telah melaksanakan tugasnya. Tak lama kemudian turunlah ayat 3 surah al-Maidah:

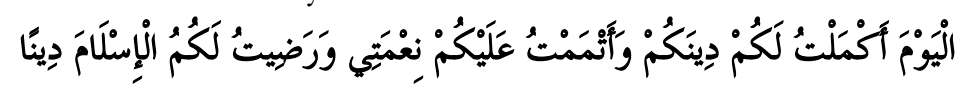

"Pada hari ini telah Kusempurnakan untuk kamu agamamu, dan telah Ku-cukupkan kepadamu nikmatKu, dan telah Ku-ridhai Islam itu Jadi agama bagimu."

Itulah beberapa ayat Al-Quran yang dijadikan kaum Syi'ah sebagai dasar atau landasan doktrin imâmah disamping merujuk kepada peristiwa Ghadir Khum tentang penunjukan Ali menjadi imam pengganti rasulullah sesudah beliau wafat. ${ }^{27}$

\section{Penutup}

Dari uraian di atas dapat disimpulkan beberapa hal yaitu: Pertama, Imâmah adalah doktrin utama kaum Syi'ah. Mereka menggunakan term imam sebagai gelar jabatan pengganti rasulullah setelah beliau wafat. Sebagaimana rasulullah, seorang imam bertugas memimpin umat dalam urusan agama dan juga urusan negara. Kaum Syi'ah khususnya Imamiyah Itsna 'Asyariyah dan Isma'iliyah berpendapat bahwa yang berhak menjadi imam adalah Ali bin Abi Thalib. Ali telah ditunjuk dan dilantik oleh rasulullah di Ghadir Khum. Kekhalifahan Abu Bakar, Umar dan Usman dianggap tidak sah karena tidak berhak menjadi khalifah, dan bahkan dianggap telah merampas hak Ali bin Abi Thalib. Sementara itu, Syi'ah Zaidiyah yang dikenal agak moderat walaupun berpendapat bahwa yang berhak menjadi imam adalah Ali bin Abi Thalib, namun mereka berpendapat bahwa rasulullah tidak pernah menunjuk dan melantik Ali menjadi imam. Rasulullah tidak pernah menetapkan siapa yang menjadi imam, beliau hanya menyebutkan sifat-sifat seorang imam dan kebetulan sifat-sifat itu dimiliki oleh Ali bin Abi Thalib, maka Alilah yang lebih utama menjadi imam.

Kedua, Menurut Syi'ah Imamiyah Itsna 'Asyariyah dan Isma'iliyah, imam harus dari keturunan rasulullah (ablul bayt) dan ditunjuk oleh beliau. Sedangkan menurut Zaidiyah imam disyaratkan keturunan rasulullah melalui Fatimah, tapi itu tidak mutlak. Jika persyaratan itu tidak terpenuhi boleh memilih imam dari pihak lain. Penunjukan imam bisa dilaksanakan lewat musyawarah atau pemilihan oleh sebuah lembaga yang bernama Ablu al-Halli wa al'Aqdi. Karena itu golongan Zaidiyah menganggap sah kekhalifahan sebelumnya. Selain itu, golongan Syi’ah Imamiyah

${ }^{27}$ Ali Assalus, Imamah dan dan Khilafah, 43 - 45. 
Itsna 'Asyariyah dan Isma'iliyah juga berpendapat bahwa seorang imam bersifat ma'shûm yakni terpelihara dari dosa dan kesalahan, sementara Zaidiyah berpendapat bahwa imam tidak ma'shûm, karena sebagai manusia, seorang imam bisa saja berbuat kesalahan dan berbuat dosa.

Ketiga, Pemikiran kaum Syi'ah mengenai imamah merujuk kepada peristiwa yang terjadi di Ghadir Khum, di mana nabi sepulang dari haji wada' langsung berhenti di Ghadir Khum wilayah Arafah, di sini beliau menunjuk dan melantik Ali bin Abi Thaib untuk menjadi pengganti beliau sebagai imam. Peristiwa ini diyakini oleh golongan Imamiyah Itsna 'Asyariyah dan Isma'iliyah sebagai dasar penunjukan Ali menjadi imam. Selain itu mereka juga menggunakan ayat-ayat Al-Quran yang dipahami dan ditafsirkan menurut versi mereka, sebagai dalil atau argumen dalam memperkuat doktrin imamah. Sementara golongan Zaidiyah tampaknya tidak memakai dalil-dalil dan peristiwa Ghadir Khum tersebut. Demikianlah beberapa kesimpulan yang dapat diambil dari uraian-uraian sekilas tentang doktrin imamah menurut kaum Syi'ah []

\section{DAFTAR PUSTAKA}

Ali Muhammad Ash-Shalabi. Khawarij dan Syi'ah Dalam Timbangan Ablu Sunnab Waljamaah, terj. Masturi Ilham \& Malik Supar. Jakarta: Penerbit Al-Kautsar, 2007.

Ali Assalus. Imamah dan Khilafah dalam Tinjauan Syar’i. Jakarta: Gema Insani Press, 1997.

Abu Zahrah. Târikh al-Mąâhbib al-Islâmiyah. Cairo: Dar al-Fikr al-‘Araby, t.th.

Ahad Daudy. Kuliah Ilmu Kalam. Jakarta: Bulan Bintang, 1997.

Harun Nasution. Islam Ditinjau Dari Berbagai Aspeknya. Jakarta: UI Press, 1985.

Suyuthi Pulungan. Fikih Siyasab: Ajaran, Sejarah dan Pemikiran. Jakarta: Rajawali Press, 1994.

Al-Syahrastani. Al-Milâl wa al-Nihâl. Cairo: Muassasah Al-Halaby, 1968.

Sayyid Mujtaba Musawi Lari. Teologi Islam Syi'ah. Terj. Tholib Anis. Jakarta: Penerbit A-Huda, 2004.

Hasan Ibrahim Hasan. Sejarah dan Kebudayaan Islam. Jakarta: Kalam Mulia, 2006.

Dedi Supriyadi. Sejarah Peradaban Islam. Jakarta: CV. Pustaka Setia, 2008. 